bouring governments would welcome it. Ethiopian border police patrols in cooperation with the game authorities could report on the extent of armed raiding parties, and ultimately make ground observation from camp in the neighbourhood of Kathangor hill-the best vantage point on the Sudan side of the border.

HUGH M. WOODMaN.

\title{
NEW MOVES IN INDIA
}

FOR some time it has been apparent that wildlife preservation in India has not been as successful as was expected when the Indian Board for Wild Life was constituted in 1952, and in April this year the Planning Commission invited a number of leading conservationists (including the writer) from different parts of India to New Delhi to discuss the situation. Their four main recommendations were:

1. Adequate funds must be made available in the Fourth Plan for the effective conservation of wildlife, and, to give impetus to the programme, the schemes envisaged should be centrally sponsored.

2. Policy decisions should be taken on some matters of all-India concern such as uniform legislation; export of wildlife and wildlife products; issue of gun licences and restrictions of manufacture, import and sale of certain types of ammunition; problems concerning tribal and rural welfare vis-a-vis wildlife preservation in and near the forests; and patterns for sanctuaries and national parks.

3. A separate Wild Life Division should be constituted in the Ministry of Food \& Agriculture, and a Wild Life Circle in each State; and the Standing Committee of the Indian Board for Wild Life should be reconstituted into a smaller body to act not only as the Executive of the IBWL but also as the Technical Advisory Committee to the proposed Wild Life Division.

4. Steps should be taken to improve education and publicity throughout India in wildlife conservation; and an expert scientific inventory of India's wildlife resources including national parks, sanctuaries and equivalent reserves should be made by competent ecologists.

These decisions were endorsed at a meeting in June of the Indian Board for Wild Life, which also made four other important recommendations :

1. That an advanced course on wildlife management be instituted at the Forest Colleges at Dehra Dun.

2. That the manufacture, import and sale of shot gun cartridges of LG and SG type be banned.

3. That the possession and use of harmful insecticides be rigidly controlled and that the matter receive the earnest attention of the Ministry concerned.

4. That India become a full member of IUCN.

It is to be hoped that the Government of India will now accept the recommendations and take the necessary steps to implement them, so that wildlife may receive a higher priority than hitherto.

E. P. GEE. 